\title{
Celebrating C. Sumner Spalding
}

\section{Robert M. Hiatt}

M ore than 150 admirers gathered March 15 at St. Barnabas Episcopal Church, Temple Hills, Maryland, to celebrate the life of Charles Sumner Spalding, who died March 8 in Baltimore from complications of pneumonia. This remarkable man was an internationally renowned authority on eataloging and an accomplished organist, composer, and band and choir director. Most of the music played at the celebration was Spalding's own. He was also a good friend whose sense of humor, devotion to others, and ability to laugh at himself were hallmarks.

Born in Somerville, Massachusetts, in 1912, Spalding received bachelor's and master's degrees in music from Harvard University in 1933 and 1934 and a master's degree from the School of Library Service, Columbia University, in 1940 before joining the Library of Congress as a music cataloger later that year. With the outbreak of World War II, Spalding took a leave of absence from the Library and joined the U.S. Army, where he served as bandmaster of the $362 \mathrm{~d}$ Army Band. Although he admitted that he had no formal training to serve as a conductor, his hard work, leadership, and concern for his troops resulted in lifelong friendships that were renewed at periodic reunions of his band members.

After the war, Spalding returned to the Library of Congress, where he served as assistant chief and chief of the Catalog Maintenance Division, chief of the Serial Record Division, chief of the Descriptive Cataloging Division, and assistant director (cataloging) (equivalent to the current position of director for cataloging), the position that he held when he retired from the Library in 1975. Upon his retirement Spalding received the Library's highest award, the Distinguished Service Award.

During his professional life, Spalding represented the Library of Congress at many national and international conferences and served on many boards and committees. The 1961 International Conference on Cataloguing Principles in Paris, at which he represented the Library, adopted an internationally accepted set of principles of choice and form of entry. These principles led to the first edition of the Anglo-American Cataloguing Rules, for which Spalding served as general editor and for which he received the Margaret Mann Citation, the highest award in cataloging and classification offered by the American Library Association. He also represented the Library at the 1969 International Meeting of Cataloguing Experts in Copenhagen, at which the machinery was set in motion for a series of International Standard Bibliographic Descriptions. At the national level, Spalding served as the Library's representative to the United States Board on Geographic Names (BGN), an interagency organization responsible for providing uniformity in geographic nomenclature and orthography throughout the federal government. At the time of his retirement he was chairman of BGN. Former director for acquisitions Glen A. Zimmerman was heard saying that Spalding was "an icon in the library world, particularly in the ares of cataloging. Sumner 
played a major role in the Cataloging in Publication Program right from the beginning. What struck me was his willingness to try something entirely different, apart from the cataloging status quo, apart from a very well-established reputation in the field."

During his retirement Spalding continued to pursue all his interests, including continuing analysis of professional cataloging matters, full participation in the musical life of several churches, and musical composition. At 81 he was granted a patent for a specialized electronic device to enhance the sound of an organ.

C. Sumner Spalding will long be remembered not only as a giant in the cataloging and classification community but also as a true Renaissance man. His two sons, Charles Spalding, Jr., and Guy W. Spalding, make their homes in the Washington area. Donations to celebrate the life of Charles Sumner Spalding can be given to St. Agnes Hospital, Baltimore, Maryland.

\section{INDEX TO ADVERTISERS}

Kapco

Library of Congress

Library Technologies

OCLC Forest Press

OCLC Online

Public Library Association

Reed Reference

Todd Enterprises
173

$2 \mathrm{~d}$ cover $3 \mathrm{~d}$ cover 178 174,253 